\title{
MERDEKA BELAJAR-KAMPUS MERDEKA IN DEVELOPING BUSINESS ENTREPRENEURS
}

\author{
By \\ Sutangsa \\ Postgraduate Lecturer at Subang University \\ Email: Sutangsapls@Gmail.Com
}

\begin{tabular}{l}
\hline \hline Article Info \\
\hline Article History: \\
Received:13-10-21 \\
Revised: 16-11-21 \\
Accepted: $24-11-2021$
\end{tabular}

Keywords:

Kampus Merdeka, Creativity,

Innovation, Entrepreneurship

\begin{abstract}
Merdeka Belajar-Kampus Merdeka is an innovative breakthrough program in building human resources full of creativity and innovation with the aim of being able to compete in the global arena. This breakthrough program policy is seen in the perspective of fostering an entrepreneurial spirit aimed at preparing students to become strong graduates, relevant to the needs of the times, and ready to become leaders with a high spirit of nationalism. Students who are currently studying at tertiary institutions, must be prepared to become true learners who are skilled, flexible and resilient (agile learners). The keywords in entrepreneurship are creativity and innovation. Emphasis on these two aspects can be seen from the learning process. Increasing and even changing the mental structure of students is expected to be oriented to innovation and creativity that have economic value. Entrepreneurial success is a part of the process of creativity and innovation, this is in line with what was stated by Schumpeter (1934) about the destruction of value in an established market structure. Entrepreneurs offer value that can change the structure of an established market. These values are formulated based on creativity and innovation.
\end{abstract}

Thisisan open accessarticleundertheCC BY-SAlicense.

CorrespondingAuthor:
Sutangsa
Postgraduate Lecturer at Subang University
Email: Sutangsapls@Gmail.Com

\section{INTRODUCTION}

The development of science and technology has created accelerated changes in all fields that affect the joints of human life. Responding to changes in the increasingly globalized world, UNESCO applies four pillars of learning, namely Learning to Know, Learning to Do, Learning to Live Together, Learning to Be. In learning to know the meaning of how to learn, learning to do contains the dimensions of human life skills, learning to live together contains a multicultural dimension of life, and learning to be implies learning to recognize one's identity, abilities and weaknesses and competencies that are mastered by humans to be able to building a complete life continuously.

The implementation of the four pillars of learning by UNESCO (2005), namely Learning to Know, Learning to Do, Learning to Live Together, Learning to Be, gave birth to the concept of a learning revolution. Modern learning models that train students to be sources of learning, change passive learning models (passive learning) to active learning (active learning), change the model of fact thinking (factual thinking) to think critically (critical thinking), from not actively responding being proactive in responding, from abstract thinking to authentic. This change places formal education in a strategic position in developing students' abilities optimally and intactly.

Indonesia is currently active in carrying out national development in various fields. This is a manifestation of the national ideals stated in paragraph 2 of the Preamble of the 1945

Constitution which is essentially the vision of the Indonesian, namely the realization of an independent, united, sovereign, just and prosperous Indonesia. This is also an embodiment of the four national goals or functions of the state based on the mission of Indonesia approved in paragraph 4 of the Preamble of the 1945 Constitution. It also helps overcome challenges and problems that arise in society, one of which is in Article 31 Paragraph (3) which reads: "The Government seeks and manages a national education system, which enhances faith and piety and noble character in the context of educating the life of the nation, which is regulated by law". 
The concrete steps taken by the government with the issuance of Law Number 20 of 2003, concerning the National Education system and Law Number 12 of 20102, concerning Higher Education and Government Regulation Number 04 of 2014, concerning the Implementation of Higher Education and Management of Higher Education.

The understanding of higher education is more clearly and completely written in Law No. 12 of 2012 concerning Higher Education in article 1 paragraph (1) states that: "Higher Education is the level of education after secondary education which includes diploma programs, undergraduate programs, master programs, doctoral programs, and professional programs, as well as specialist programs, organized by universities based on Indonesian culture.”

The Higher Education with its function, as stated in Law No. 12 of 2012 Article 4 that higher education has 3 (three) functions as follows: (1) Developing capabilities and shaping the character and civilization of a dignified nation in the context of developing the intellectual life of the nation. (2) Developing an innovative, responsive, creative, skilled, competitive, and cooperative Academic Community through the implementation of Tridharma, and (3) Developing Science and Technology by paying attention and applying Humanities values.

Correspondingly, with the aim of Higher Education, the purpose of higher education is also contained in Law No. 12 of 2012 concerning Higher Education namely in article 5. In Law

No. 12 of 2012 article 5 mentioned 4 (four) objectives of higher education, namely as follows: (1) The development of the potential of students to become human beings who believe and fear God Almighty and have noble, healthy, knowledgeable, capable, capable, creative, independent, skilled, competent, and cultured for the benefit of the nation. (2) Generating graduates who master the branches of Science and / or Technology to meet national interests and increase national competitiveness. (3) The Generating of Science and Technology through Research that pays attention to and applies the value of the Humanities to be beneficial for the progress of the nation, as well as the progress of civilization and the welfare of humanity. (4) Realization of Community Service based on reasoning and research work that is useful in advancing public welfare and intellectual life of the nation.

One of the national development sectors that is currently managed and developed is by rolling out the Merdeka Belajar-Kampus Merdeka program in the perspective of building an entrepreneurial spirit. Merdeka Belajar - Kampus Merdeka Permendikbud No. 3 of 2020 concerning National Standards of Higher Education is a legal umbrella that has been issued at this time.

By taking into account these conditions, universities for their role as institutions / institutions that run and educate millennials must seriously take various steps that lead to the measurement of the Merdeka-Campus Learning program mentioned. So that this program can maximize the achievement of strong and measurable human resources.

Based on this line of thought, education is an important aspect for a person in the life of the state. According to Ki Hajar Dewantara, education is the process of guiding all natural forces that exist in students, so that they as humans and as members of the community can achieve the highest safety and contentment.

Similarly, in terms of human resources (HR) in this case the subject is students, there are several theories in the effort to develop human resources so that the quality is improved by continuously forging through various education or training with various expertise, especially in the discussion which can build an entrepreneurial spirit. Thus, these are steps as well as efforts to strengthen the competitiveness of Human Resources (HR) as a means of supporting national development in all fields.

Efforts to create quality human resources that can improve the welfare of the community need to be continued through education. With quality education and ability or skills, human resources are expected to become quality resources and have a major contribution to the development process now and in the future.

Suryana (2003) stated that entrepreneurship is an ability in creating added value in the market through the process of managing resources in new and different ways through: (1) development of new technologies. (2) The discovery of new scientific knowledge. (3) Repair of existing goods and services. (4) The discovery of new ways to produce more goods with more efficient resources.

The objectives of the entrepreneurial activity program include: (1) providing students with an interest in entrepreneurship to develop their business earlier and be guided. (2) addressing the problem of unemployment which results in intellectual unemployment among scholars.

From this statement can provide a clear picture that the purpose of developing human resources through education is so that every Indonesian human who is a student can have and develop potential that is not only for the interests that are needed by himself, but furthermore that potential can benefit the community as well as the nation. The potential that must be possessed by every human of Indonesia is the potential that is rooted in religious values, national culture so that this potential becomes the individual character that shapes the human character of Indonesia.

Thus, the Merdeka Belajar- Kampus Belajar national education program can be used as one of the tools, facilities and the main key to realizing national development goals, namely to create a society that is just and prosperous, physically and physically prosperous. 
International Journal of Social Science (IJSS)

Vol.1 Issue.4 December 2021, pp: 385-392

ISSN: 2798-3463 (Printed) | 2798-4079 (Online)

DOI: https://doi.org/10.53625/ijss.v1i4.590

\section{DISCUSSION}

Merdeka Belajar - Kampus Merdeka is the policy of the Minister of Education and Culture, which aims to encourage students to master various sciences that are useful for entering the workforce. Merdeka Campus provides an opportunity for students to choose the courses they will take, including the ability to build an entrepreneurial spirit. In this context, students will be taught or educated to learn material about entrepreneurship. Being an entrepreneur of course is a basic right of all of us. Do not because just because we do not have descendants of entrepreneurs, so close the opportunity to become entrepreneurs. The first step we take if we are interested in going into the world of entrepreneurship is to foster an entrepreneurial spirit within us.

Based on the Global Entrepreneurship Index (GEI) in 2018, Indonesia only had a score of $21 \%$ of entrepreneurs in various occupations, or ranked 94 out of 137 countries surveyed. Meanwhile, according to research from the IDN Research Institute in 2019, 69.1\% of millennials in Indonesia have an interest in entrepreneurship. So it is unfortunate that the potential for entrepreneurship for the millennial generation has not been well managed so far. The Merdeka Belajar- Kampus Merdeka Policy Merdeka encourages the development of student entrepreneurial interests with appropriate learning activities programs.

According to Tilaar (2000) education is an expenditure that is increasing and increasingly focused on the interests of every child and family; The economy asks for an educated workforce to increase productivity. Education is the development of human resources. The purpose of education as the development of human resources is the development of the potential that exists in each individual as an individual in relation to community life. Education as the development of human resources is to develop personal responsibility for improving the quality of life of individuals, as well as personal responsibility in building society. Thus, education not only increases knowledge, but also improves work skills which in turn will increase work productivity.

According to Hidayat (in the book Tilaar, 2000) that an area will not be able to be built if the area is not able to develop the knowledge and skills of its people and utilize it effectively for development purposes.

Quality education will guarantee the continuity of regional development. Education is very important in finding a good future. Education is the basic capital of development that needs to be maintained. The government needs to strive for expansion and equitable distribution of opportunities to obtain quality education for the community, provision of educational facilities and infrastructure. In addition, various proactive and reactive efforts that support the potential of individual communities need to be done. Educational materials provided by students, in this case students, are often less relevant to the needs of national development.

1. Entrepreneurial Behavior

Entrepreneurship is described by creativity and innovation. Entrepreneurship according to Daryanto (2012, p.3) is a discipline that can be learned and taught. Affirmed as a discipline of Behavioral Entrepreneurship is not only an innate talent or field affair, but is learned and taught. Zimmerer (1996, p.51) argues that Entrepreneurial Behavior as a result of the discipline, systematic process of applying creativity and innovation in meeting market needs and opportunities. It is explicitly explained that Entrepreneurial Behavior is the process of applying creativity and innovation to solve problems and explore opportunities faced by everyone in each outcome.

Furthermore according to Hendrati and Mochson (2010, p.30) the definition of entrepreneur is someone who is able to combine various resources to produce new products / services, product development, new technologies, new marketing channels so as to increase wealth by bearing various risks such as capital, time or commitment.

The opinion about the understanding of entrepreneurship above is reinforced by Scarborough \& Zimmerer (1993, p.5), namely "people who create new business in the face of risk and uncertainty for the purpose of achieving profit and growth by identifying opportunities and gathering keyword sources to identify entrepreneurs are courage face risks and uncertainties, identify opportunities and take advantage of opportunities. Meanwhile Howard Aldrich \& Catherine Zimmer (1986) in an article titled "Entrepreneurship Through Social Networks" in the ontology "The Art And Science of Entrepreneurship", defining Entrepreneurship is a process and must be seen in dynamic terms rather than snap-cross- sectional and entrepreneurship requires relationships or relationships between key components of the process.

In general Lioyd and Robbins (2014, p.39) explained that Entrepreneurs are described as people who feel business opportunities and utilize scarce resources to use them profitably. Entrepreneurs dare to bear risks that can not be insured, directing human and material resources in their business goals. Latent psychological features can emerge and develop with training. Based on this definition, Howard criticized the traditional conception of entrepreneurship, which used three approaches, namely First, using personality theory, Second, using economic, rational actor theories, and Third, using deterministic, oversocialized models.

From the understanding of entrepreneurship from the experts above, a common thread can be drawn that the understanding from the aspect of entrepreneurship is a science that can be learned, taught, and is the result of a process 
of discipline, innovation, and hard work to read market opportunities, and market needs so that they can create opportunities to produce products or services with the risks faced so that desired goals (profits) are achieved. In this study, entrepreneurial behavior is a function of individual interaction in the learning process and the environment in order to realize self-actualization in the economic empowerment of the community.

2. Entrepreneurship Objectives

The conclusion from some of the notions of entrepreneurship above is obtained as an overview of entrepreneurial goals ranging from simple goals to more complete goals. These objectives include:

a) Realizing innovative ideas.

b) Create new and different values.

c) Deconstructing the economic order by introducing products, services, creating valuable management, and exploring limited resources in the business.

d) A process to produce new output.

e) Creating innovation and creativity in solving problems in business.

f) Develop new ideas and find new ways to solve problems and take advantage of opportunities.

g) Discover new ways of thinking and apply the results of these thoughts to the value creation process.

The above objectives are in line with Jean B. Say (1800) in Alma (2011, p. 29) which states that the goal of entrepreneurship is to move various economic resources from an area with low productivity to an area of higher productivity and greater results. Therefore, that goal contains nodes related to innovative ideas, creating new businesses, and making products that have no sale value to have economic value.

3. Entrepreneurship Characteristics

The various types of key businesses must have a character that is disciplined, honest, trustworthy and easy to get along with. However, the characters above are common characters, therefore, entrepreneurial characteristics include, as follows:

Table 1. Characteristics Of Entrepreneurs (Meredith, 1982)

\begin{tabular}{|c|c|c|}
\hline No & Dimension & Behavior Indicator \\
\hline 1 & Confidence & $\begin{array}{l}\text { - Level of Confidence / confidence (constancy) } \\
\text { - Independence, have an independent personality } \\
\text { - optimism }\end{array}$ \\
\hline 2 & Task and Results Oriented & $\begin{array}{l}\text { - Needs achievement } \\
\text { - Results oriented (profit) } \\
\text { - Diligent and stoic } \\
\text { - Determination, ready to work hard, highly motivated } \\
\text { - energetic } \\
\text { - Full of initiative }\end{array}$ \\
\hline 3 & Dare to take risks & $\begin{array}{l}\text { - The level of courage to take risks } \\
\text { - Liked the challenges at a moderate level }\end{array}$ \\
\hline 4 & Leadership & $\begin{array}{l}\text { - Ability to influence } \\
\text { - Inspire others } \\
\text { - Stimulating the intellectuals of others } \\
\text { - Helping inexperienced people become experienced }\end{array}$ \\
\hline 5 & Originality & $\begin{array}{l}\text { - Innovative (innovator) } \\
\text { - creative } \\
\text { - flexible } \\
\text { - Many sources } \\
\text { - Multi talented } \\
\text { - Knowledgeable }\end{array}$ \\
\hline 6 & Future Oriented & $\begin{array}{l}\text { - Foresight } \\
\text { - Broader perspective in understanding the problems. }\end{array}$ \\
\hline
\end{tabular}

a) Confidence (self confidence)

The attitude and confidence to start, do and complete a task or job at hand. Self- confidence describes the ownership of the values of belief, optimism, and individuality and independence. Someone who has confidence tends to have confidence in his ability to achieve success. Self-confidence is an individual internal factor that is relative and dynamic. Someone who has high 
International Journal of Social Science (IJSS)

Vol.1 Issue.4 December 2021, pp: 385-392

ISSN: 2798-3463 (Printed) | 2798-4079 (Online)

DOI: https://doi.org/10.53625/ijss.v1i4.590

confidence in general will have the ability to complete work systematically, plan, effectively, and efficiently. Trust is shown by the excitement, and the stability in doing work.

Self-confidence as a strong foundation to increase value creation. Every work produced grows and enhances self-confidence. The level of creativity, initiative, work enthusiasm and perseverance encourage someone to work better for inner satisfaction. In the end it strengthens confidence. Someone who has confidence has the ability to work alone in organizing, overseeing, and achieving output according to plan.

b) Task and Results Oriented

Task and outcome oriented means that each effective and efficient task implementation correlates with results. Result and task oriented means having the motive of achievement, profit orientation, having the perseverance and fortitude to excel, having the determination to work hard, having a strong drive, energetic, and initiative. Initiative means always wanting to find and start value creation. To begin, it requires strong intention and determination, and the right intention. In entrepreneurship, opportunities are only obtained if there are initiatives and the behavior of these initiatives is usually obtained through internships and years of experience, their development is obtained by self-discipline, critical thinking, responsiveness, passion, and a spirit of achievement. Success increases self-confidence to succeed in the next activity. Sudjana (2016, p. 41) explains the main dimensions in tasks and outcomes are 1) grades; 2) feedback; 3) perseverance; 4) sustainability.

c) Dare to take risk

Entrepreneur is a person who prefers businesses that are more challenging to achieve success or failure than less challenging businesses. Courage to bear the risk of being an entrepreneurial value. Risk taking is supported by mature and realistic calculations. Stelmach and Vroon (1994, p.14) explain that courage at risk in business is behavior that is ready to deal with uncertain conditions. Courage includes aspects such as physical and psychosocial.

The level of courage to take risks is influenced by several factors, namely: (1) self- confidence; (2) willingness to use the ability to look for opportunities and benefit from risks; (3) the ability to assess the risk situation realistically. Sujana (2016, p.42) conveyed the Dimension that needs to be understood inherent in the courage to take risks. namely (1) the ability to take and analyze risk, (2) anticipation (optimal change for survival), (3) endurance (risk acceptance). d) Leadership

Successful entrepreneurs have a leadership spirit. Entrepreneurs always want to appear different, earlier and more prominent, entrepreneurs always display the goods and services they produce faster, earlier, and immediately on the market. Entrepreneurs try to produce new and different products and services, meaning that they are pioneers in both the production and marketing processes. Entrepreneurs always take advantage of differences as something that adds value. Therefore, the difference for someone who has an entrepreneurial spirit is a source of renewal to create value. Entrepreneurs always want to hang out to look for opportunities, open to accept criticism and suggestions which are used as an opportunity. In their works and works, entrepreneurs want to always look new and different. Work and initiative will be seen as something new and used as opportunities.

e) Originality

An entrepreneur is a person who is innovative, creative, and flexible. Innovative is reflected because it can create new things that can be accepted by society. The innovation will bring up Innovation. Innovation is the practical application of creative ideas Conny Semiawan $(1984$, p.8) in Alma (2011, p.68) states that creativity is the ability to create a new product. New product means not entirely new, but only product parts.

f) Future Oriented

Entrepreneurs have a far-sighted future, they are always to work and to have initiative. The key is in the ability to create something new and different from what already exists. Dimensions in the orientation towards the future are 1) having clear business goals and directions; 2) explore value opportunities and opportunities; 3) focus.

The practices, concepts and characteristics of entrepreneurs continue to develop including the age of the entrepreneurs. Entrepreneurs are not only dominated by productive age in the general sense, namely pre-adulthood until before retirement. Weller et al (2014) in their research showed an increase in the population of entrepreneurs in America who come from retirement age which is considered unproductive. Older workers face an increase in lifespan and increased labor market uncertainty which could lead to considering entrepreneurship as an increasingly attractive option. Weller et al (2014, p.152) convey that having substantial capital income raises the opportunity of being an entrepreneur including among retirees. Older entrepreneurs experience an increase in wealth and income security that is higher than the salaries and salaries of employees or independent employees. An entrepreneur has a high motivation to meet the needs of life independently, and dare to take risks.

3. Entrepreneurship Skills

Skills related to business activities are quite diverse. Skills that are general to specific skills to complete a particular job. Entrepreneurial skills according to Hofmuth (2014: 68) are social skills (business networks), system skills (decision making), resource management skills.

Regarding life skills, Sahuu and Gupta (2013, p. 77) as important aspects to face challenges in life. Life skill is defined as the level of ability to adapt and behave positively to meet and face life's challenges. Life skills are fundamental starting from the ability to make decisions to solve problems, think creatively and critically, interpersonal skills, empathize and calm in the face of pressure / workload. In business activities economic pressures such as inflation or weak public purchasing power have an impact on business activities. In general, Life skills are needed so that participants can live in society and provide value for the realization of a more prosperous society.

Entrepreneurial skills can be said as part of general life skills. Suryadi (2009, p.135) suggested life skills, namely: 1) personal skills, namely self awareness, and rational thinking skills; 2) social skills (social skills); 3) academic skills (academic skills); and 4) vocational skills (vocational skills) as shown in the following figure: 


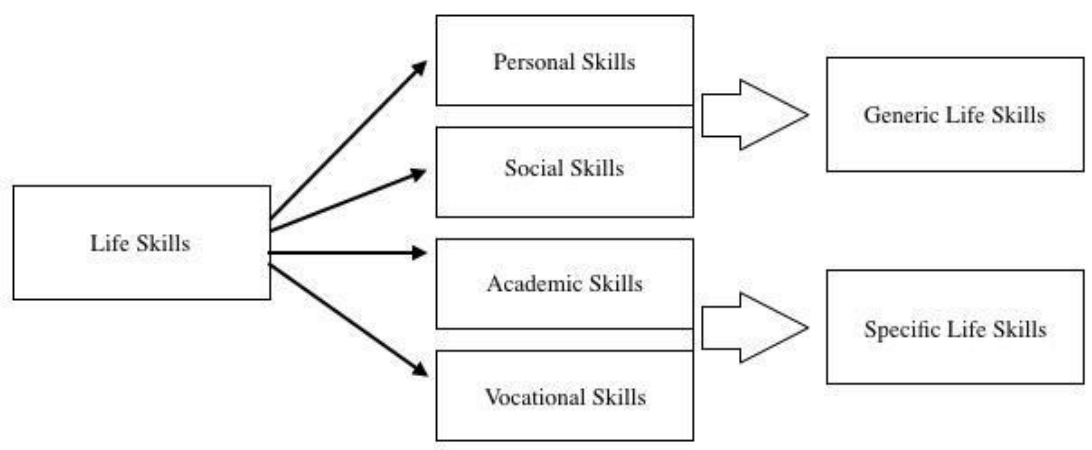

Picture 1. Types Of Life Skills

Source: Suryadi, 2009, p.136.

Based on this concept life skills can be divided into two: First, generic life skills (generic life skills / GLS), consisting of personal skills (personal skills / PS) and social skills (social skills / SS). Personal skills consist of the skills to understand themselves (self awareness), self- awareness or thinking skills, and social skills are the skills to interact or communicate (communication skills) and work together (collaboration skills). Second, specific life skills (specific life skills / SLS), which consists of skills to deal with work or certain circumstances. Specific Life Skills which include academic skills or intellectual skills and vocational skills.

Regarding the specific skills that are used to manage the value creation activities creatively and innovatively. Skills are needed to create value. Entrepreneurial ability according to Stuetzer (2013, p.1184) in accordance with needs according to the current situation. Entrepreneurial ability will result in effective and efficient value creation as stated earlier by Elmuti (2012, p.85). Mcelwee (2006, p.198) describes entrepreneurial skills as the ability to enable the diversification of products, services, processes and inputs and outputs that demonstrate an innovative and creative process. Skills related to entrepreneurship have a dimension of relevance to current conditions.

Previously, Iradale (2002, p.3), strengthened by Vaidya (2014, p.7) showed the dimensions of entrepreneur skills, namely problem solving, creativity, persuasion, planning, negotiation, decision making. Elmuti (2012: 83) explains the dimensions of entrepreneurial skills, which are the skills needed by entrepreneurs divided into three different categories: technical skills (knowledge applied to specific jobs), business management skills (business management including planning for new businesses) and personal skills such as the ability to communicate and understand customer needs.

Based on the opinions of experts, in this study entrepreneurial expertise is defined as specific abilities that are relevant to the current needs to improve the efficiency and effectiveness of value creation for the community through the productive economy. The dimensions of entrepreneurial skills are social skills (Persuasiveness, communication / good relations with others, customers, communities, competitors, colleagues), conceptual skills (problem identification, problem solving) and managerial skills (decision making, product diversification planning) and technical skills ( knowledge applied to certain jobs).

Based on the opinion of experts in general regarding Entrepreneurial Behavior above, the dimensions of Entrepreneurial Behavior in relation to the study are used (1) Confidence; (2) Task and Results Oriented; (3) Dare to take risks; (4) Leadership; and (5) originality.

4. Personal Characteristics

Each individual has a different character. This shows that humans as Infrahuman beings have identities that cannot be divided so that they differentiate themselves from others in terms of their physical characteristics. Humans as individuals are related to the uniqueness inherent in human beings. Someone determines themselves and has characteristics. As a human person, someone describes themselves with quality or identity. Sihotang (2016, p.35) argues that the source of human uniqueness is spiritual. From a psychological aspect, Brooks (2006, p.14) explains that the individual's specific personality characteristics may be open or hidden and which can determine either similarities or differences in behavior. This means that humans have similarities as economic creatures, religious beings or thinking creatures.

\section{REFERENCES}

[1] Daryanto. (2012). Pengantar Kewirausahaan. Jakarta: Prestasi Pustakaraya.

[2] Elmuti., D et al. (2012). Does Entrepreneurship Education Have A Role In Developing Entrepreneurial

[3] Skills And Ventures' Effectiveness? Journal of Entrepreneurship Education, 15 pp 83-98. International Small Business Journal: Researching Entrepreneurship.pp 1-26

[4] Hendrati, Ignatia M \& Mochson, M. (2010). Latar Belakang Pendidikan, Pelatihan dan Jiwa 
International Journal of Social Science (IJSS)

Vol.1 Issue.4 December 2021, pp: 385-392

ISSN: 2798-3463 (Printed) | 2798-4079 (Online)

[5] Kewirausahaan Terkait Kinerja Keuangan UKM. Kediri: Universitas Nusantara PGRI.

[6] Hofmuth, M. (2014). Matthias Hofmuth Identifying Knowledge , Skills And Abilities Of Successful

Entrepreneurs, 55-75

[7] Howard Aldrich \& Catherine Zimmer. (1986). Small business still speaks with the same voice: a replication of 'the voice of small business and the politics of survival' RKP pp 335-356.

[8] Komar, (Prosiding). "PAUD, Investasi Generasi". Pemetaan Pembangunan Berkelanjutan Penguatan Pendidikan Nonformal dan Informal di Indonesia.

[9] Lloyd, J. E., Robbins, I. O., Lloyd, J. E., \& Robbins, I. O. (2014). Relevance To Serving Directors In The Nigerian Public Service :, 2(4), 38-60

[10] Sutangsa, (Disertasi), dengan judul "Pemberdayaan Kesejahteraan Ekonomi Produktif Masa Persiapan Pensiun Aparatur Sipil Negara (ASN)" .

[11] Simamora.,S (1995). Manajemen Sumber Daya Manusia. STIE YKPN. Yogyakarta.

[12] Suryana. (2001). Kewirausahaan, Pedoman Praktis, Kiat, dan Proses Menuju Sukses. Jakarta: Salemba Empat.

[13] Sudjana.D (2007 Manajemen Program Pendidikan (Pendidikan Nonformal dan Pengembangan Sumber Daya Manusia). Bandung : Falah.

[14] Suryadi,A (2009) Mewujudkan masyarakat Pembelajar. Bandung Widya Aksara.

[15] Stuetzer., $M$ et al (2013) Where do entrepreneurial skills come from?applied economic letter 20(12).pp:1183-1186.

[16]Undang-Undang Nomor 12 Tahun 2012, tentang Pendidikan Tinggi.

[17]Peraturan Pemerintah Nomor 04 Tahun 2014, tentang Penyelenggaraan Pendidikan Tinggi dan Pengelolaan Perguruan Tinggi.

[18]Permendikbud No. 3 Tahun 2020 tentang Merdeka Belajar - Kampus Merdeka.

[19]Vaidya. ,(2014). Developing Entrepreneurial Life Skills: Creating and Strengthening Entrepreneurial Culture in Indian Schools.

[20]Zimmerer, W. Thomas, and N.M Scarborough, 2008. "Essentials of Entrepreneurship and Small Business Management" (Kewirausahaan dan Manajemen Usaha Kecil ), edisi 5 Buku 1 Bahasa Indonesia. Jakarta: Salemba Empat

[21]Buku Panduan Penyelenggaran Merdeka Belajar - Kampus Merdeka. 
